\title{
Modelling the Effects of Soil Conditions on Olive Productivity in Mediterranean Hilly Areas
}

\author{
Ashraf Tubeileh, ${ }^{1,2}$ Francis Turkelboom, ${ }^{1,3}$ Anwar Al-Ibrahem, ${ }^{4}$ \\ Richard Thomas, ${ }^{1}$ and Kholoud Sultan-Tubeileh ${ }^{2}$ \\ ${ }^{1}$ International Center for Agricultural Research in the Dry Areas, P.O. Box 5466, Aleppo, Syria \\ ${ }^{2}$ University of Guelph, Kemptville Campus, P.O. Box 2003, Kemptville, ON, Canada K0G 1J0 \\ ${ }^{3}$ Research Group of Nature and Society, Research Institute for Nature and Forest, 1070 Brussels, Belgium \\ ${ }^{4}$ General Commission for Scientific Agricultural Research, Department of Olive Research, Idleb, Syria
}

Correspondence should be addressed to Ashraf Tubeileh; ashraf.tubeileh@uoguelph.ca

Received 18 July 2014; Accepted 18 September 2014; Published 19 October 2014

Academic Editor: David Clay

Copyright (C) 2014 Ashraf Tubeileh et al. This is an open access article distributed under the Creative Commons Attribution License, which permits unrestricted use, distribution, and reproduction in any medium, provided the original work is properly cited.

\begin{abstract}
The majority of olive (Olea europaea L.) production in Mediterranean environments is characterized by low external inputs and is practiced in hilly areas with shallow soils. This study aimed to study the yield and nutritional status for olive (cv. "Zeiti") trees in northwestern Syria and establish correlations between yield, on the one hand, and soil/land factors and tree nutrition, on the other hand, to determine the most yield-affecting factors. Land and soil fertility parameters (field slope, soil depth, and soil nutrients) and concentrations of leaf minerals were determined. As olive roots can go deep in the soil profile to extract nutrients, the total available nutrients per tree (over the whole profile) were estimated. Multiple regression analyses were performed to determine the model that best accounts for yield variability. Total available soil potassium amount $\left(R^{2}=0.68\right)$, soil total $\mathrm{N}$ amount $\left(R^{2}=0.59\right)$, and soil depth $\left(R^{2}=0.56\right)$ had the highest correlations with olive fruit yields. Available soil potassium amount and soil depth explained together $77 \%$ of the yield variability observed. In addition to these two factors, adding leaf $\mathrm{B}$ and Fe concentrations to the model increased the variability explained to $83 \%$.
\end{abstract}

This paper is dedicated to the good memory of Mr. Malek Abdeen.

\section{Introduction}

Olive trees have played an important role in the rural development of the Mediterranean's relatively poor rainfed areas over the centuries [1]. The maintenance of traditional olive groves is crucial for the environment, as these systems show high levels of biodiversity and soil conservation [2,3], especially given that most olive groves are established on sloping lands. For example, $84 \%$ of rainfed olive trees in Andalusia are grown on slopes greater than $5 \%$ [4].

This study was carried out in Aleppo Governorate in northern Syria. Olive productivity in this part of Syria lags behind other producing areas of similar climatic conditions and some fields are being deserted. External inputs are low and consist, when practiced, of sheep manure every second or third year $[5,6]$, due to farmers' perception that olive trees do not need to be fertilized. Moreover, the export of pruning material for animal feed or combustion results in nutrient mining and nutrient export from the area, which is typical for rainfed dry areas [7]. The combination of these management factors with the high erosion rates results in shallow soil depths that can be as low as $10 \mathrm{~cm}$ in severe cases.

According to Klewinghaus et al. [8], erosion in Afrin area is function of relief parameters (i.e., slope gradient, aspect, curvature, landform elements, and upslope area), agricultural practices, land use and vegetation cover, and roads and buildings. In the same area, Hoorelbeke [9] found that soils of olive groves established on forest lands cleared a few decades ago were shallower by $31 \%$ and less fertile by $50 \%$ than neighbouring conifer forest land. The main causes for this degradation 
were the lack of vegetation cover, the intensive subsequent tillage operations, and the lack of sufficient manure or fertilizer application. This researcher also reported that two-thirds of the interviewed farmers had observed a declining yield trend due to soil erosion. Barneveld et al. [10] estimated the actual annual soil loss in Afrin area to reach $8 \mathrm{~kg} \mathrm{~m}^{-2}$ with five cultivator passes per year on an olive grove with an average slope of $25 \%$. To compensate for this loss, some farmers purchase soil and add it under the tree canopy to increase soil depth and replenish soil fertility [11].

In spite of these studies, there is almost no information on the overall effect of soil status on olive yield. Furthermore, literature information on the relation between soil and leaf nutrient status and yield is not straight forward and is mostly obtained through fertilizer trials. While most literature studies (e.g., [12-14]) indicated that adding $\mathrm{N}$ resulted in higher leaf $\mathrm{N}$ concentrations, some authors (e.g., [15]) reported that $\mathrm{N}$ fertilization did not translate into higher yields. Similarly, there is no agreement among researchers with regard to the relationship between olive yield and leaf $\mathrm{K}$ and $\mathrm{P}$ concentrations. For instance, Jasrotia et al. [16] noticed a strong negative correlation between olive yield and leaf minerals $\mathrm{P}, \mathrm{K}, \mathrm{Ca}$, and $\mathrm{Mg}$, whilst Sharma et al. [17] reported that maximum leaf concentration values of these minerals (in addition to $\mathrm{N}$ ) ensured regular olive bearing behaviour. Working on carob, another evergreen Mediterranean tree, Correia et al. [18] found that $92 \%$ of carob yield variability may be related to leaf concentration of N, P, K, Mn, and Fe. Marcelo and Jordão [15] did not find an effect of $\mathrm{K}_{2} \mathrm{O}$ addition on olive yields. The above studies were designed as fertilizer rate studies and did not include a wide range of nutrient concentrations or other variables that could interact with the element in question (e.g., soil volume explored by the tree). It is therefore fair to conclude that the occurrence of fertilization effects depends on soil nutrient levels, balanced fertilization, and the duration of the study. The assessment of these effects can contribute to a better identification of bottlenecks for olive productivity in the area and therefore formulate targeted fertilizer and land management recommendations for olive growers. The objectives of the present study were to

(i) present the characteristics of a typical low input olive system in the eastern Mediterranean,

(ii) identify key nutrient deficiencies in marginal-land olive groves,

(iii) present strategies for orchard and nutrient management,

(iv) present recommendations for further research.

\section{Methodology}

This study was carried out in 2005 in Afrin district, Aleppo Governorate, northwestern Syria. To model the effects of land and soil parameters on olive yields, parameters such as land slope, soil depth, soil bulk density, organic matter content, and chemical soil fertility were measured as detailed below. It is assumed that soil moisture will be correlated to soil depth. In addition, concentrations of leaf minerals were also determined. Our methodology relied on establishing simple and multiple regressions to find the model that best describes the variability observed.

2.1. Study Area. Afrin district is known to be the first producer of olive oil in Syria with its 10+ million trees [19]. The locally predominant "Zeiti" cultivar ranks first in Syria in terms of number of trees and oil content, which exceeds $30 \%$ (on dry weight basis) in its natural habitat [20, 21]. Lands in Afrin area are sloping and are prone to erosion due to wide tree planting distance $(\sim 10 \mathrm{~m} \times 10 \mathrm{~m})$, up-down tillage, minimal canopy size induced by severe pruning every second or third year, and absence of cover crops. Afrin area features low mountains (up to $\sim 700 \mathrm{~m}$ asl) and gently undulating rounded limestone hills. According to Cools et al. [22], the deeper soils in the calcareous hills are mainly Calcaric Cambisols, while the shallower soils are classified as Hypersceletic Leptosols, and Leptic Regosols [23]. Soils are slightly alkaline with $\mathrm{pH}$ ranging between 7.2 and 8.4. Calcium carbonate levels ranged between 20 and $480 \mathrm{~g} \mathrm{~kg}^{-1}$ [22]. The climate in the area is a typical Mediterranean with rainy cold winters and dry hot summers. Average annual rainfall in the area ranges between 440 and $470 \mathrm{~mm}$ in the valleys and 600 and $700 \mathrm{~mm}$ on hilltops. The amount of rainfall recorded in Afrin in 2005 was $461 \mathrm{~mm}[19]$.

The sites where the trees were selected are located between longitudes $36^{\circ} 5694 \mathrm{E}$ and $37^{\circ} 1256 \mathrm{E}$ and latitudes $36^{\circ} 2245 \mathrm{~N}$ and $36^{\circ} 5688 \mathrm{~N}$ (Figure 1). The elevation of the selected groves ranged between 282 and $654 \mathrm{~m}$ asl, and the mean value was $464 \mathrm{~m}$ asl.

2.2. Criteria for Tree Selection. In order to clearly identify yield-controlling factors, the fields were selected to account for maximum diversity of soil and land factors available in the area. For example, whenever possible, trees with different soil depths were sampled on the same site. However, only healthy looking trees were selected and any disease-affected trees or those with visible disorders were avoided as those disorders might distort normal yield relations. It is assumed that largesize trees selected in flat areas with deep soils would represent optimum rainfed, low-input growing conditions and yield for the area.

In spring (March-April) 2005, fifty trees were selected and marked from 25 orchards across Afrin area. The number of trees per orchard varied from one to three according to the uniformity of the sites. In sites with variable tree size and/or soil conditions (depth, land slope, etc.), two or three trees were selected to better represent that variability. The following criteria were considered in tree selection.

(i) Trees belong to the "Zeiti" cultivar, being the dominant cultivar in the area.

(ii) Trees are in their bearing (on) year.

(iii) Trees are in stable commercial production stage (older than 15 years, less than 80 years).

(iv) Trees are representative for the grove or a significant part of it. 


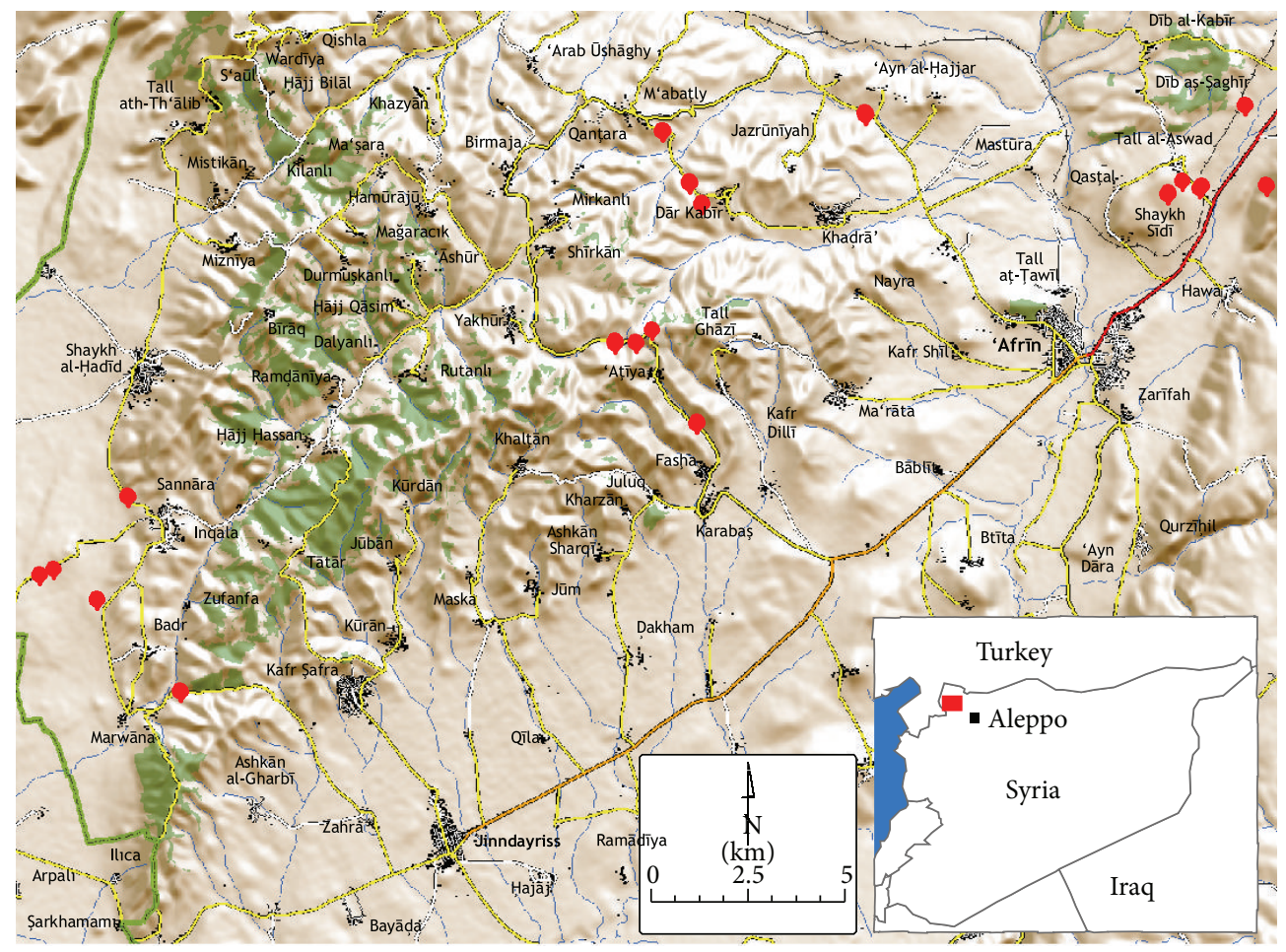

$$
\begin{array}{ll}
\text { Sampled orchard } & \begin{array}{l}
\text { Paved connecting road } \\
\text { (by decreasing importance) }
\end{array} \\
+- \text { International border } & - \\
++ \text { Railway } & - \\
\text { - Built up area } & \text { Partially paved road } \\
\text { Stream } & \begin{array}{l}
\text { Unpaved road/ } \\
\text { Fillage street }
\end{array}
\end{array}
$$

FIGURE 1: A topography map of northwestern Aleppo Governorate showing Afrin area with the orchard locations (red dots).

(v) Trees were pruned after 2003 harvest in a similar way (heavy pruning every second year after a good crop, resulting in a full crop every second year with no crop in the other year).

(vi) Trees have only one main trunk.

(vii) Trees are healthy and do not show pest infection or disorder symptoms.

(viii) No trees were selected on north-facing slopes, which can have particular microclimatic conditions.

(ix) Trees are rainfed (i.e., no irrigation is applied).

(x) No fertilizer or manure was added this year or during the past 2 years.

(xi) Soil is traditionally ploughed 4-6 times per year to increase rainwater infiltration, control weeds, and destroy capillary evaporation.

Most of the selected grove owners were already known to Agricultural Extension agents in Afrin, which facilitated the selection of trees, and ensured the collection of good-quality data. Age of the selected trees varied between 18 and 80 years, with a mean value of 50 years. Field slope ranged between $0 \%$ and $38 \%$ with a mean value of $7.4 \%$.

2.3. Soil and Plant Characteristics. Field slope was estimated using an inclinometer. Since visual soil colour is one of the favourite indicators local farmers use to describe a soil [9], a simple characterization of soil colour (i.e., white, brown, red, and black and their gradients) was visually performed in May and June 2005 after the end of the rainy season when the topsoil was dry. Based on field observations and literature data showing that olive roots can extend deeply in the soil, the complete soil depth was measured by augering soil profile at two opposite points one meter away from the tree trunk. Soil augering was then divided into $20 \mathrm{~cm}$ increments, and one composite sample was taken for each depth increment and analyzed separately to account for soil fertility in the complete profile, rather than simply using nutrient concentrations for the topsoil (which is the common approach). Stones were separated from soil particles by wet sieving through a $2 \mathrm{~mm}$ mesh, and the stone volumetric fraction in each increment was computed. Undisturbed soil clods were also 
TABLE 1: Analytical methods used to determine soil physical and chemical properties.

\begin{tabular}{lcc}
\hline Element & Method and analysis equipment & Reference \\
\hline Soil bulk density & Undisturbed clod method & Blake (1965) [24] \\
Soil organic matter & Walkley-Black method & Walkley and Black (1934) [25] \\
Nitrogen & Kjeldahl wet digestion & Bremner and Mulvaney (1982) [26] \\
Available phosphorus & Olsen colorimetry & Olsen and Sommers (1982) [27] \\
Extractable potassium & Extractable potassium, Flame Photometer 409 & Richards (1954) [28] \\
Extractable boron & Spectrocolorimetry & Bingham (1982) [29] \\
Iron, copper & DTPA test. Atomic Absorption Spectrometry & Lindsay and Norvell (1978) [30] \\
\hline
\end{tabular}

collected for bulk density determination. Soil bulk density, organic matter, total nitrogen, mineral $\mathrm{N}$, and available concentrations of $\mathrm{P}, \mathrm{K}$, and $\mathrm{B}$ were determined using the methods described in Table 1.

The rootzone was assumed to have a cylindrical shape and to compute its volume, the soil depth (to a maximum depth of $1.7 \mathrm{~m}$ ) was measured for each tree, and the root radius was estimated to be $3 \mathrm{~m}$ based on planting density. The amount of each element $(A$, in $\mathrm{kg})$ in the tree rootzone was computed by summing up the amounts for each increment, according to the following formula:

$$
A=\sum C_{i}\left(V_{\text {tot }}-V_{\text {stone }}\right) \times \mathrm{BD},
$$

where $C$ is nutrient concentration $\left(\mathrm{kg} \mathrm{kg}^{-1}\right)$ in each soil increment $i, V_{\text {tot }}$ is soil volume with stones $(\mathrm{L}), V_{\text {stone }}$ is volume of stones in the increment, and BD is bulk density $\left(\mathrm{kg} \mathrm{L}^{-1}\right)$.

These mineral elements will be referred to as total $\mathrm{N}_{\text {rootzone }}$, mineral $\mathrm{N}_{\text {rootzone }}, \mathrm{P}_{\text {rootzone }}, \mathrm{K}_{\text {rootzone }}$, and $\mathrm{B}_{\text {rootzone, }}$ respectively. In addition to the amounts of mineral elements in the soil, the concentration of those elements in the top $20 \mathrm{~cm}$ soil layer will be presented to give an idea about soil fertility levels independently from variable soil depths.

Approximate tree age was determined through discussions with grove owners and/or by expert visual assessments. Yield per tree (in terms of fresh fruit weight) was assessed in November 2005.

To study tree nutritional status and its relationship with yield, leaf samples were collected in late April 2005 before flowering to determine concentrations of $\mathrm{N}, \mathrm{P}, \mathrm{K}, \mathrm{Fe}, \mathrm{Cu}, \mathrm{Mn}$, $\mathrm{Zn}$, and $\mathrm{B}$ on a dry weight basis. From each tree, 50-60 fully expanded leaves, initiated during 2004, were selected between the fourth and sixth pairs of leaves below the shoot tip from different parts of the tree, as suggested by Bouat [31]. Leaves were dried in a fan-assisted oven at $85^{\circ} \mathrm{C}$ for four days. Leaf $\mathrm{N}$ concentration was determined using the Kjeldahl wet digestion method. For leaf $\mathrm{P}$ concentration, the sample was digested by Kjeldahl wet digestion method (in concentrated $\mathrm{H}_{2} \mathrm{SO}_{4}$ at $490^{\circ} \mathrm{C}$ for 3 hours) and $\mathrm{P}$ concentration was determined by spectrometry. For $\mathrm{K}$ and microelements $(\mathrm{Fe}, \mathrm{Cu}$, and $\mathrm{B})$, the stored samples were ashed in a muffle furnace at $525^{\circ} \mathrm{C}$ for 6 hours and dissolved in $2 \mathrm{M}$ $\mathrm{HCl}$. K concentration was determined using Flame Photometer 410 (Sherwood Scientific Ltd., Cambridge, UK) while $\mathrm{Fe}$ and $\mathrm{Cu}$ were determined using Atomic Absorption Spectrometer 374 (PerkinElmer, Wellesley, MA, USA). Leaf B concentration was determined by spectrometry. For leaf $\mathrm{Mn}$ and $\mathrm{Zn}$ concentrations, the samples were wet-digested using $\mathrm{HNO}_{3}-\mathrm{HClO}_{4}[32]$ and the concentrations were determined by Atomic Absorption Spectrophotometry.

2.4. Statistical Analysis. The statistical analysis was performed on 47 trees after dropping three outliers due to tree health reasons (e.g., disease on tree or fruit, physi$\mathrm{cal} / \mathrm{mechanical}$ damage) developing after the tree selection. To evaluate the influence of external factors (i.e., soil depth, soil B amount, soil K amount, soil mineral $\mathrm{N}$ amount, and soil exchangeable $\mathrm{P}$ amount) on final tree yields, simple regressions were made between yield and each factor. A multiple regression analysis was then performed to determine the model that best accounts for the variance. Although multiple regression analysis is the standard approach in biological and ecological system modelling, the inherent collinearity (multicollinearity) of confounded explanatory variables could encumber analyses and threaten their statistical and inferential interpretation [33]. However, since our goal of conducting multiple regressions is to develop a model that best predicts variability in the response, then the problems due to multicollinearity can be effectively ignored.

Correlations between fruit production and leaf mineral concentrations were also examined to understand the contribution of these minerals to fruit yield. Analysis of variance was performed for all the simple and multiple regressions established. Regressions were considered statistically significant at the $P<0.05$ level. Statistical analysis and correlations were performed using SPSS 14.0 software [34].

\section{Results}

3.1. Soil Fertility. Soil colour in the selected groves differed from white (originated from chalky limestone) to basalticorigin black soil (Table 2). For a given site, soil fertility levels decreased in the lower soil layers compared to the topsoil. The topsoil was considered as a basis for comparison given the differences in soil depth. A huge variation among the selected sites was discovered with regard to the concentration of organic matter and nutrients in the topsoil, especially with regard to $\mathrm{K}$ concentration, which varied from 14 to $386 \mathrm{mg} \mathrm{kg}^{-1}$ (Figure 2). Red soils, mainly on limestone parent material, generally had the highest organic matter and nutrient concentrations followed by dark brown and black soils, respectively. White and grey soils had the lowest organic matter and $\mathrm{K}$ concentrations. $\mathrm{P}$ concentrations in the topsoil 
TABLE 2: Characteristics and fertility levels of the topsoil $(0-20 \mathrm{~cm})$ for the selected trees.

\begin{tabular}{|c|c|c|}
\hline Tree number & Visual soil colour & Soil depth (m) \\
\hline 1 & Light black & 0.30 \\
\hline 2 & Brown & 1.20 \\
\hline 3 & Light black & 0.20 \\
\hline 4 & Light black & 0.20 \\
\hline 5 & Light black & 0.20 \\
\hline 6 & Light black & 0.20 \\
\hline 7 & Red & 0.60 \\
\hline 8 & Light brown & 0.70 \\
\hline 9 & Brown & 0.90 \\
\hline 10 & Brown-white & 0.20 \\
\hline 11 & Brown-white & 0.40 \\
\hline 12 & White-grey & 0.50 \\
\hline 13 & White-grey & 0.30 \\
\hline 14 & White & 1.20 \\
\hline 15 & White & 0.70 \\
\hline 16 & White & 0.80 \\
\hline 17 & Brown & 0.20 \\
\hline 18 & Brown & 0.20 \\
\hline 19 & Brown-red & 0.25 \\
\hline 20 & Brown-red & 0.20 \\
\hline 21 & Brown-red & 0.25 \\
\hline 22 & Grey & 0.15 \\
\hline 23 & Grey & 0.15 \\
\hline 24 & Grey & 0.30 \\
\hline 25 & Red & 0.30 \\
\hline 26 & Red & 0.15 \\
\hline 27 & Dark brown & 0.60 \\
\hline 28 & Dark brown & 0.50 \\
\hline 29 & Grey & 0.20 \\
\hline 30 & Grey & 0.40 \\
\hline 31 & Grey & 0.25 \\
\hline 32 & Discarded & 0.60 \\
\hline 33 & Light brown & 0.90 \\
\hline 34 & Light brown & 0.70 \\
\hline 35 & Black & 1.10 \\
\hline 36 & Black & 1.20 \\
\hline 37 & Dark brown & 1.60 \\
\hline 38 & Dark brown & 1.70 \\
\hline 39 & Pale brown & 0.60 \\
\hline 40 & Light brown & 0.60 \\
\hline 41 & Red & 0.50 \\
\hline 42 & Red & 0.30 \\
\hline 43 & Red & 0.30 \\
\hline 44 & Discarded & 0.60 \\
\hline 45 & White & 0.20 \\
\hline 46 & Discarded & 0.60 \\
\hline 47 & Grey & 0.40 \\
\hline 48 & Grey & 1.00 \\
\hline 49 & Grey & 0.40 \\
\hline 50 & Brown & 0.80 \\
\hline
\end{tabular}

TABLE 2: Continued.

\begin{tabular}{cc}
\hline Tree number $\quad$ Visual soil colour & Soil depth $(\mathrm{m})$ \\
\hline Minimum value & 0.15 \\
Maximum value & 1.70 \\
Median value & 0.40 \\
Mean & 0.536 \\
Standard error & 0.055 \\
\hline
\end{tabular}

of the selected fields ranged between 2.4 and $23.2 \mathrm{mg} \mathrm{kg}^{-1}$ and were within the same ranges for all soil colours. Extractable boron concentrations were highest in black (and grey) soils $\left(2.86 \mathrm{mg} \mathrm{kg}^{-1}\right)$, while the maximum concentration recorded for any other soil colour was $1.27 \mathrm{mg} \mathrm{kg}^{-1}$ (brown soil). There was no correlation between topsoil fertility and soil depth, and the highest soil organic matter level was detected in a soil that was $30 \mathrm{~cm}$ deep.

3.2. Tree Nutrient Status and Fruit Yield. Most of the trees monitored had leaf nutrient concentration values below deficiency thresholds reported in the literature (Table 3). Still, no visible nutrient deficiency symptoms were detected on any of those trees. Almost three of every four trees had leaf $\mathrm{N}$ concentrations lower than the deficiency threshold level of $14 \mathrm{~g} \mathrm{~kg}^{-1}$ (in July) reported by Freeman et al. [35] in California, and 12 trees were below Bouat's critical value of $12 \mathrm{~g} \mathrm{~kg}^{-1}$ in France [31]. It is interesting to highlight that leaf $\mathrm{N}$ concentration was not correlated with soil depth.

The mean leaf $\mathrm{P}$ concentration was exactly at the deficiency threshold level, and 29 trees were located below that threshold. Tree K nutrition was better than the other primary macroelements as half the trees did not have deficient leaf $\mathrm{K}$ concentration values and the mean leaf $\mathrm{K}$ concentration was slightly higher than the deficiency threshold. All the trees with higher leaf $\mathrm{K}$ concentrations were located on red, dark brown, or black soils.

Wide ranges were also observed for leaf micronutrient concentrations. For 26 trees, leaf $\mathrm{Cu}$ concentration values were right at the threshold level and only four trees were below that level. For leaf Fe concentration, there is no information available on deficiency threshold in olive. Boron nutrition did not seem to be a concern, as only five trees had leaf B concentration levels slightly below deficiency threshold.

Olive fruit yield varied considerably among the trees. Four trees produced less than $11 \mathrm{~kg}$ tree $^{-1}$, while ten trees produced more than $40 \mathrm{~kg}$ tree $^{-1}$. In general, trees grown on red soils tended to have the highest yields and those on white and grey soils had the lowest yields.

3.3. Simple Regressions between Soil and Land Factors and Yield. To identify the most important soil and land factors in determining yield and to separate the individual effects of each of those factors, simple regression analyses were carried out between each soil and land factor and tree yield (Table 4). The most important factor was $\mathrm{K}_{\text {rootzone }}$, explaining 


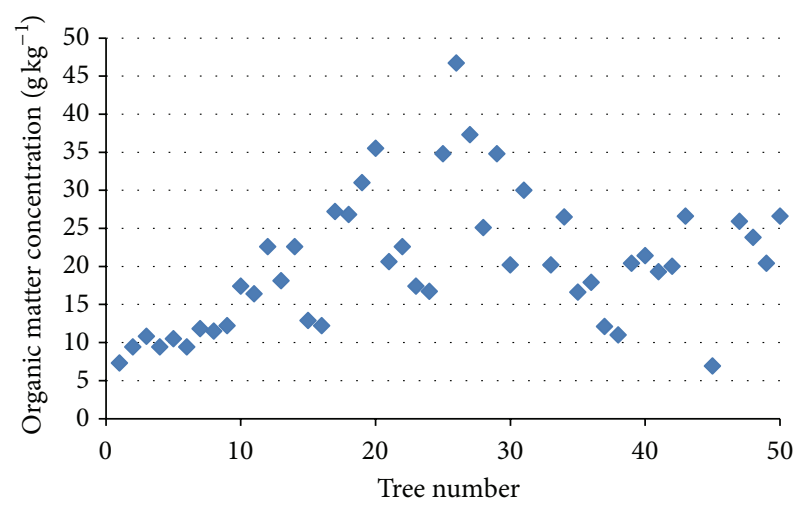

(a)

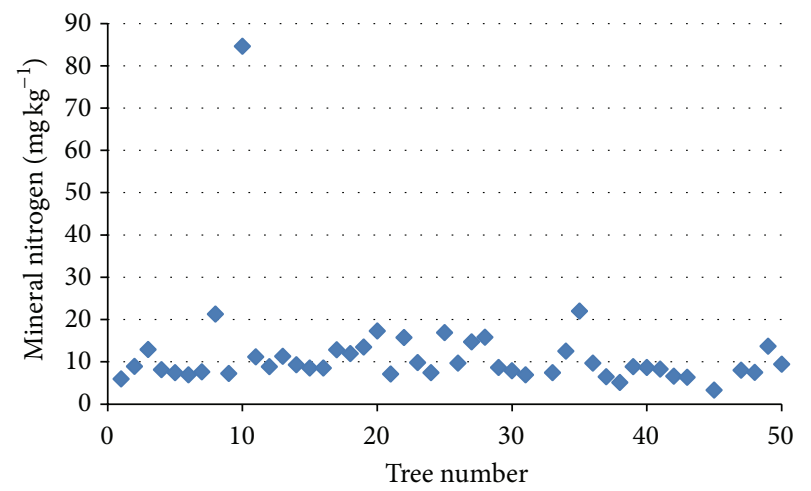

(c)

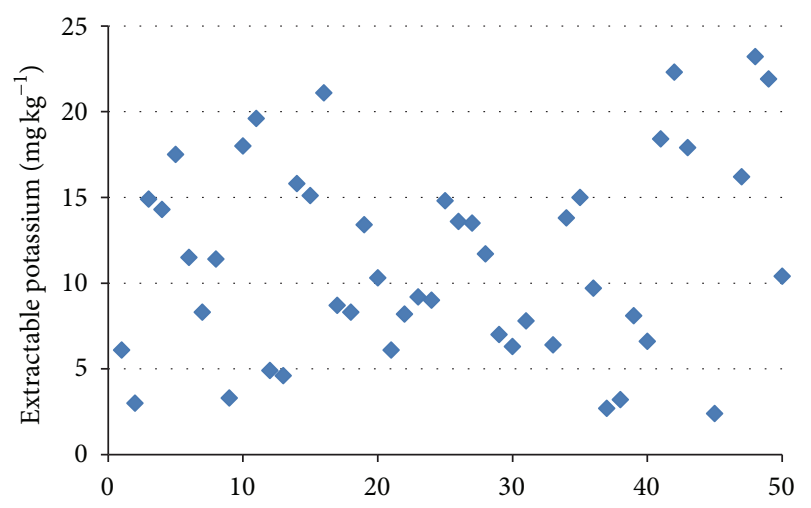

(e)

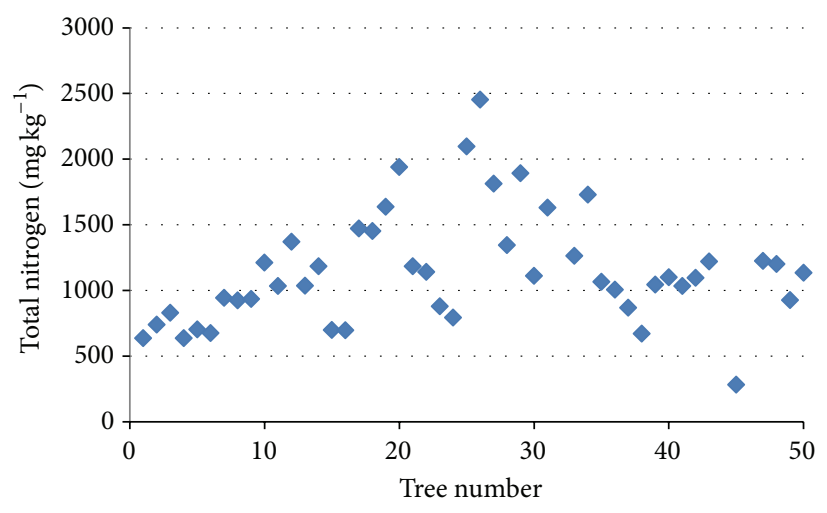

(b)

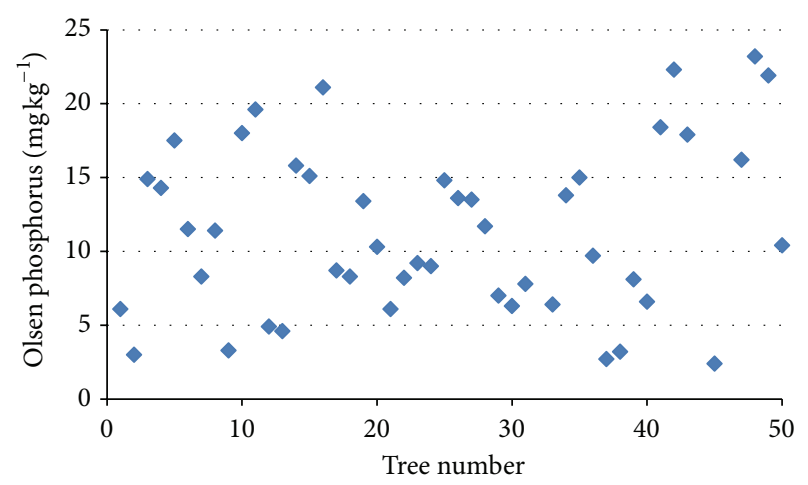

(d)

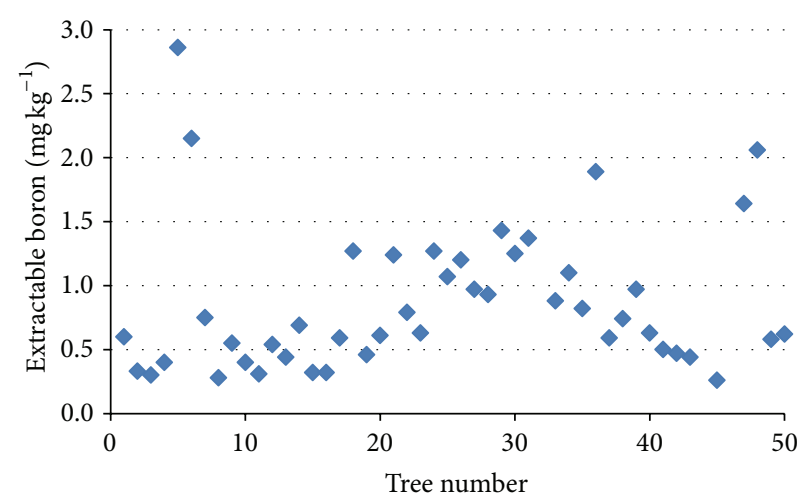

(f)

FIGURE 2: Fertility levels in the topsoil $(0-20 \mathrm{~cm})$ : (a) organic matter, (b) total nitrogen, (c) mineral nitrogen, (d) Olsen phosphorus, (e) extractable potassium, and (f) extractable boron.

two-thirds of the yield variability according to the following relationship:

$$
\begin{gathered}
Y=21.4( \pm 2.16) \log (\mathrm{K})+30.7( \pm 1.28) \\
R^{2}=68.4 \%, \quad P<0.001,
\end{gathered}
$$

where $Y$ is yield and $\mathrm{K}$ is the total amount of available $\mathrm{K}$ in the rootzone soil per tree. The numbers in parentheses represent the standard error. A logarithmic curve explained more variability than a linear relation (Figure 3 ).

Total $\mathrm{N}_{\text {rootzone }}$ ranked second with $58 \%$ of the variability explained, while soil depth was the third most important factor affecting tree yield, explaining $56 \%$ of the variability
(Figure 4). The logarithmic relation for soil depth proved to account for more variability than the linear one. Interestingly, leaf $\mathrm{K}$ concentration was significantly correlated to soil depth, unlike leaf $\mathrm{N}$ or leaf $\mathrm{P}$ concentrations (Table 5).

Other soil factors related to nutrients were also important. Mineral $\mathrm{N}_{\text {rootzone }}$ and $\mathrm{B}_{\text {rootzone }}$ accounted, respectively, for $44 \%$ and $41 \%$ of the total variability (Table 4 ) and the correlations were statistically significant. On the other hand, olive fruit yield was not significantly correlated to soil organic matter content.

3.4. Multiple Regressions between Soil/Land Factors and Yield. Multiple regression analysis data are presented in 
TABLE 3: Leaf mineral composition of main macro- and micronutrients and olive fruit yield.

\begin{tabular}{|c|c|c|c|c|c|}
\hline Parameter & $\begin{array}{l}\text { Deficiency } \\
\text { thresholds* }\end{array}$ & $\begin{array}{c}\text { Number of trees } \\
\text { below deficiency } \\
\text { threshold }\end{array}$ & Minimum & $\begin{array}{c}\text { Mean }( \pm \text { standard } \\
\text { error })\end{array}$ & Maximum \\
\hline $\begin{array}{l}\text { Leaf } \mathrm{N} \text { concentration } \\
\left(\mathrm{g} \mathrm{kg}^{-1}\right)\end{array}$ & 14.0 & 34 & 9.5 & $12.9( \pm 0.2)$ & 15.6 \\
\hline $\begin{array}{l}\text { Leaf } \mathrm{P} \text { concentration } \\
\left(\mathrm{g} \mathrm{kg}^{-1}\right)\end{array}$ & 1.0 & 29 & 0.7 & $1.0( \pm 0.2)$ & 1.4 \\
\hline $\begin{array}{l}\text { Leaf } \mathrm{K} \text { concentration } \\
\left(\mathrm{g} \mathrm{kg}^{-1}\right)\end{array}$ & 4.0 & 24 & 1.2 & $4.4( \pm 0.3)$ & 10.7 \\
\hline $\begin{array}{l}\text { Leaf Cu concentration } \\
\left(\mathrm{mg} \mathrm{kg}^{-1}\right)\end{array}$ & 5.0 & 4 & 2.50 & $5.80( \pm 0.28)$ & 10.0 \\
\hline $\begin{array}{l}\text { Leaf Fe concentration } \\
\left(\mathrm{mg} \mathrm{kg}^{-1}\right)\end{array}$ & Unknown & $\mathrm{N} / \mathrm{A}$ & 25.0 & $56.8( \pm 2.68)$ & 110 \\
\hline $\begin{array}{l}\text { Leaf B concentration } \\
\left(\mathrm{mg} \mathrm{kg}^{-1}\right)\end{array}$ & 14 & 5 & 12.8 & $18.2( \pm 0.57)$ & 29.4 \\
\hline $\begin{array}{l}\text { Leaf } \mathrm{Mn} \text { concentration } \\
\left(\mathrm{mg} \mathrm{kg}^{-1}\right)\end{array}$ & 20 & 6 & 15.0 & $19.0( \pm 0.56)$ & 25.0 \\
\hline $\begin{array}{l}\text { Leaf } \mathrm{Zn} \text { concentration } \\
\left(\mathrm{mg} \mathrm{kg}^{-1}\right)\end{array}$ & Unknown & $\mathrm{N} / \mathrm{A}$ & 9.0 & $12.7( \pm 0.31)$ & 15.5 \\
\hline Fresh fruit yield $\left(\mathrm{kg}\right.$ tree $\left.{ }^{-1}\right)$ & N/A & N/A & 6 & $30.2( \pm 2.26)$ & 65 \\
\hline
\end{tabular}

${ }^{*}$ Deficiency thresholds as suggested by Freeman et al. (2005) [35].

TABLE 4: Regressions between olive fruit yield $(Y)$ and external factors $(x)$. Coefficients of determination $\left(R^{2}\right)$ and statistical significance $(P)$ are also presented. Models are sorted in descending order of $R^{2}$.

\begin{tabular}{|c|c|c|c|}
\hline Yield vs. parameters & Model & $R^{2}$ & $P<$ \\
\hline $\mathrm{K}_{\text {rootzone }}$ & $Y=21.4 \log (x)+30.7$ & 0.68 & 0.001 \\
\hline Total $\mathrm{N}_{\text {rootzone }}$ & $Y=13.4 \log (x)-1.47$ & 0.58 & 0.000 \\
\hline Soil depth & $Y=38.3 \log (x)+44.7$ & 0.56 & 0.000 \\
\hline $\mathrm{K}_{\text {topsoil }}$ & $Y=0.0953 x+17.0$ & 0.47 & 0.000 \\
\hline Mineral $\mathrm{N}_{\text {rootzone }}$ & $Y=10.4 \log (x)+54.2$ & 0.44 & 0.001 \\
\hline $\mathrm{B}_{\text {rootzone }}$ & $Y=-7784.9 x^{2}+1221.4 x+19.0$ & 0.41 & 0.001 \\
\hline $\mathrm{P}_{\text {rootzone }}$ & $Y=9.90 \log (x)+55.7$ & 0.27 & 0.023 \\
\hline Slope & $Y=-1.0133 x+37.8$ & 0.21 & 0.009 \\
\hline Altitude & $Y=0.0006 x^{2}-0.5474 x+157$ & 0.19 & 0.01 \\
\hline Soil organic matter in topsoil & $Y=-3.86 x+38.1$ & 0.05 & 0.14 \\
\hline
\end{tabular}

Table 6. Combining "Log $\mathrm{K}_{\text {rootzone" }}$ with "Log $\mathrm{N}_{\text {rootzone" }}$ explained $71 \%$ of the total variability, while combining "Log $\mathrm{K}_{\text {rootzone }}$ with "Log soil depth" explained $77 \%$ of the total variability as (3) shows:

$$
\begin{gathered}
Y=15.3( \pm 2.44) \log (\mathrm{K})+19.0( \pm 4.85) \log (D) \\
+37.8( \pm 2.12) \\
R^{2}=76.6 \%, \quad P<0.001 .
\end{gathered}
$$

However, a model that combines these three factors did not improve the model $\left(R^{2}=0.77\right)$ as compared to (3), and

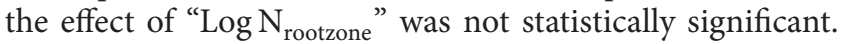
Consequently, "Log $\mathrm{N}_{\text {rootzone }}$ " was dropped from the final model.

The analysis of best subsets showed that other soil factors had no or very little addition to the final model, so they were excluded. On the other hand, the addition of tree-related parameters significantly improved the model. Leaf macronutrients did not add much to the variability explained, but micronutrients were more important. The biggest improvement in the variability explained by the model was brought in by adding "Leaf Fe" and "Leaf B" concentrations to the first two components as shown in

$$
\begin{gathered}
Y=12.4( \pm 2.44) \log (\mathrm{K})+17.6( \pm 4.26) \log (D) \\
+0.79( \pm 0.31) \text { Leaf } \mathrm{B}+0.17( \pm 0.05) \text { Leaf Fe } \\
+13.1( \pm 6.88) \\
R^{2}=83.0 \%, \quad P<0.000 .
\end{gathered}
$$

3.5. Correlations between Leaf Minerals and Yield. Interestingly, fruit yield did not correlate well with leaf $\mathrm{N}$ or $\mathrm{P}$ concentrations but correlated significantly with leaf $\mathrm{K}$ with $26 \%$ of the variability explained (Table 7 ). For micronutrients, 


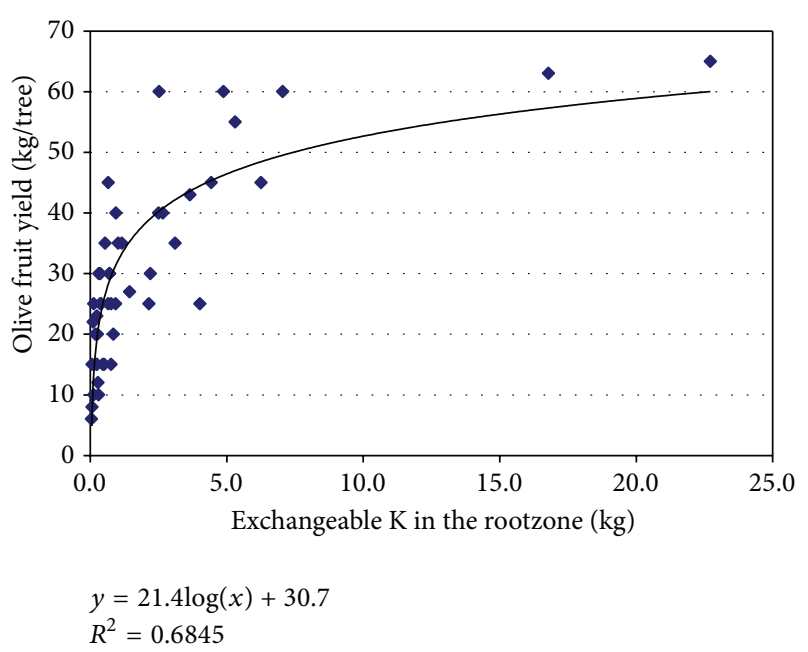

FIGURE 3: Regression between individual olive tree fruit yield $(N=$ 47 ) and the amount of exchangeable potassium in the rootzone.

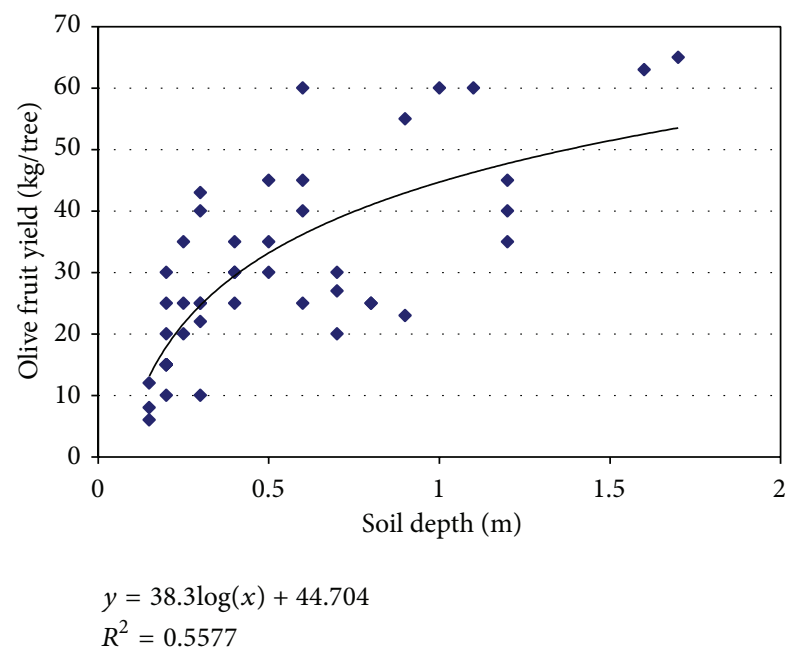

FIgURE 4: Regression between individual olive tree fruit yield $(N=$ 47) and soil depth.

fruit yield was significantly correlated with leaf $\mathrm{B}$ and $\mathrm{Fe}$ concentrations, which, respectively, explained $35 \%$ and $10 \%$ of the total variability. On the other hand, leaf $\mathrm{Mn}, \mathrm{Zn}$, and $\mathrm{Cu}$ concentrations were not correlated to fruit yield.

\section{Discussion}

4.1. Characteristics of a Typical Low Input Olive System in the Eastern Mediterranean. Soil fertility in our study is considered on the low end when compared to results from rainfed Mediterranean basin olive groves, although these levels of fertility are not uncommon. In a soil fertility survey across olive groves in Sidi Bouzid area (northwestern Tunisia), which has rainfall and topography characteristics comparable to Afrin area, Gargouri and Mhiri [36] reported values between 6 and $19.9 \mathrm{mg} \mathrm{kg}^{-1}$ for $\mathrm{P}$ (average of $11.8 \mathrm{mg} \mathrm{kg}^{-1}$ ) and between 90 and $270 \mathrm{mg} \mathrm{kg}^{-1}$ for $\mathrm{K}$ (average of $\left.133 \mathrm{mg} \mathrm{kg}^{-1}\right)$ in the top soil layer $(0-30 \mathrm{~cm})$. Similarly, our soil $\mathrm{K}$ concentrations were within the same range of recent results from one Andalusian farm reported by RestrepoDiaz et al. [37] showing $61-171 \mathrm{mg} \mathrm{K} \mathrm{kg}^{-1}$ for the topsoil $(30 \mathrm{~cm})$. However, our $\mathrm{P}$ and $\mathrm{K}$ levels were lower than survey results from Andalusian olive groves showing extractable $\mathrm{K}$ concentrations in the top $30 \mathrm{~cm}$ to range between 105 and $565 \mathrm{mg} \mathrm{kg}^{-1}$ [38]. Extractable P levels in the same study ranged between 60 and $162 \mathrm{mg} \mathrm{kg}^{-1}$. In Portugal, Marcelo and Jordão [15] reported 95 and $191 \mathrm{mg} \mathrm{kg}^{-1}$ for available $\mathrm{P}$ and $\mathrm{K}$, respectively, in the topsoil $(0-20 \mathrm{~cm})$ of a calcareous olive grove. The lower values we observed compared to Spanish and Portuguese levels could be attributed to the lower inputs in our study area.

4.2. Nutrient Deficiencies. Mineral composition of leaves in our study was often below sufficiency threshold values, especially for macronutrients. However, no nutrient deficiency symptoms could be detected in any of the orchards studied. This might be explained by the fact that nutrient concentrations below the critical level can occur long before any deficiency symptoms appear on the leaves [35].

Comparing our leaf nutrition results with other Mediterranean areas shows that our trees have consistently lower values. Leaf $\mathrm{N}$ concentrations in our study were lower than those recorded by Tubeileh et al. [39] in April for young "Qaisi" olive trees in an arid area (220 $\mathrm{mm}$ annual rainfall) in Aleppo Governorate, Syria, which ranged between 15 and $17 \mathrm{~g} \mathrm{~kg}^{-1}$ for rainfed and deficit-irrigated trees, respectively. Moreover, our values for leaf $\mathrm{N}, \mathrm{P}$, and $\mathrm{K}$ concentrations were lower than the values obtained by Dimassi et al. [40] on 17 European cultivars grown in Greece. Similarly, in a study conducted on rainfed olive trees in Cordoba, Spain, Fernández-Escobar et al. [41] observed leaf $\mathrm{N}$ concentration values around $16 \mathrm{~g} \mathrm{~kg}^{-1}$ for one-year-old leaves sampled in April (bearing year). Results from Andalusia, Spain, compiled by Ferreira Llamas [42], showed higher leaf nutrient concentrations than ours. In general, low leaf $\mathrm{K}$ concentration values are common in rainfed olive trees [43] and were observed in some foothill orchards in California [35]. However, leaf $\mathrm{K}$ values in our study were within the same range of those observed by Fernández-Escobar et al. [41], which were around $5 \mathrm{~g} \mathrm{~kg}^{-1}$ in April and slightly above $4 \mathrm{~g} \mathrm{~kg}^{-1}$ in May for one-year-old leaves sampled in an "on" year. Survey results from Tunisia [36] showed similar leaf $\mathrm{P}\left(0.58-1.4 \mathrm{~g} \mathrm{~kg}^{-1}\right)$ and generally higher $\mathrm{K}$ (4.3-9.3 $\mathrm{g} \mathrm{kg}^{-1}$ ) concentrations than our trees.

Leaf micronutrient concentrations in our study were generally above the deficiency threshold. Our mean value for leaf B concentration was comparable to the levels of $16.7 \mathrm{mg} \mathrm{kg}^{-1}$ for rainfed trees and $17-18 \mathrm{mg} \mathrm{kg}^{-1}$ for irrigated trees found by Androulakis et al. [44] in Crete but lower than Andalusian values $\left(29 \mathrm{mg} \mathrm{kg}^{-1}\right)$ reported by FernándezEscobar et al. [41]. Our leaf Fe concentrations were generally higher than those reported by Fernández-Escobar et al. [41]. Nevertheless, leaf $\mathrm{Fe}$ analysis is generally not useful for diagnosing Fe deficiency because the inconsistency of leaf Fe levels in separating chlorotic from nonchlorotic leaves [45], relying on visual leaf assessment, remains the most reliable 
TABLE 5: Regressions between olive leaf primary macronutrient concentrations $(Y)$ and soil depth $(x)$. Coefficients of determination $\left(R^{2}\right)$ and statistical significance $(P)$ are also presented. Models are sorted in descending order of $R^{2}$.

\begin{tabular}{lccr}
\hline Leaf minerals vs. soil depth & Model & $R^{2}$ & \\
\hline Leaf K concentration & $Y=0.11 \log (x)+0.54$ & 0.12 & 0.019 \\
Leaf P concentration & $Y=-0.07 \log (x)+0.10$ & 0.03 & 0.21 \\
Leaf N concentration & $Y=1.31 e^{-0.032 x}$ & 0.01 & 0.50 \\
\hline
\end{tabular}

TABle 6: Multiple regressions between olive fruit yield $(Y)$ and soil/land factors $(x)$. Coefficients of determination $\left(R^{2}\right)$ and statistical significance $(P)$ are also presented.

\begin{tabular}{|c|c|c|c|}
\hline Yield vs. parameters & Model & $R^{2}$ & $P<$ \\
\hline $\mathrm{K}_{\text {rootzone }}+\mathrm{N}_{\text {rootzone }}$ & $Y=15.4 \log (\mathrm{K})+12.8 \log \left(\mathrm{N}_{\text {rootzone }}\right)+16.7$ & 0.71 & 0.000 \\
\hline $\mathrm{K}_{\text {rootzone }}+$ depth & $Y=15.3 \log (\mathrm{K})+19.0 \log (D)+37.8$ & 0.77 & 0.0001 \\
\hline $\mathrm{K}_{\text {rootzone }}+$ depth + Tot $\mathrm{N}_{\text {rootzone }}$ & $Y=15.9 \log (\mathrm{K})+20.3 \log (D)-2.21 \log \left(\mathrm{N}_{\text {rootzone }}\right)+40.7$ & 0.77 & 0.000 \\
\hline $\mathrm{K}_{\text {rootzone }}+$ depth + leaf B & $Y=12.5 \log (\mathrm{K})+19.2 \log (D)+0.73$ leaf $\mathrm{B}+24.5$ & 0.79 & 0.000 \\
\hline $\mathrm{K}_{\text {rootzone }}+$ depth + leaf Fe & $Y=15.4 \log (\mathrm{K})+17.3 \log (D)+0.165$ Leaf $\mathrm{Fe}+27.8$ & 0.79 & 0.000 \\
\hline $\mathrm{K}_{\text {rootzone }}+$ depth + leaf $\mathrm{B}+$ Leaf $\mathrm{Cu}$ & $Y=13.6 \log (\mathrm{K})+17.5 \log (D)+0.59$ Leaf $\mathrm{B}+1.46$ Leaf $\mathrm{Cu}+18.0$ & 0.82 & 0.000 \\
\hline $\mathrm{K}_{\text {rootzone }}+$ depth + leaf B + Leaf Fe & $Y=12.4 \log (\mathrm{K})+17.6 \log (D)+0.79$ Leaf $\mathrm{B}+0.17$ Leaf $\mathrm{Fe}+13.1$ & 0.83 & 0.000 \\
\hline
\end{tabular}

TABLE 7: Correlations between olive fruit yield $(Y)$ and leaf nutrients $(x)$ sorted in descending order of $R^{2}$. Coefficients of determination $\left(R^{2}\right)$ and statistical significance $(P)$ are also presented.

\begin{tabular}{lccr}
\hline Yield vs. parameters & Model & $R^{2}$ & $P<$ \\
\hline Leaf B concentration & $Y=44.4 \log (x)-97.7$ & 0.35 & 0.000 \\
Leaf K concentration & $Y=14.9 \log (x)+44.5$ & 0.10 & 0.000 \\
Leaf Fe concentration & $Y=14.5 \log (x)-27.8$ & 0.07 & 0.032 \\
Leaf Cu concentration & $Y=12.2 \log (x)+9.45$ & 0.037 & 0.073 \\
Leaf Mn concentration & $Y=11.4 \log (x)-49.8$ & 0.038 & 0.491 \\
Leaf Zn concentration & $Y=10.8 e^{0.028 x}$ & 0.00 & 0.486 \\
Leaf P concentration & $Y=20.6 e^{2.52 x}$ & 0.00 & 0.657 \\
Leaf N concentration & $Y=20.9 e^{0.1748 x}$ & 0.75 \\
\hline
\end{tabular}

method for diagnosing Fe deficiency. On the other hand, leaf $\mathrm{Cu}, \mathrm{Zn}$, and $\mathrm{Mn}$ concentrations in our trees were substantially lower than the concentration observed by FernándezEscobar et al. [41], who reported values of $\sim 27,16$ and $30 \mathrm{mg} \mathrm{kg}^{-1}$, for the three elements, respectively, for leaves sampled in April.

Our generally low soil and leaf macronutrient values can be attributed to the fact that olive trees in this part of Syria, like most Mediterranean olive growing regions, are usually grown on poor, hilly, and shallow soils. In addition, traditional no input or low input production systems do not compensate for crop nutrient uptake. Olive growers add organic amendments (mostly manure) once every two or three years while mineral fertilizer application is almost nonexistent in dryland olive groves. Most pruning residues are also removed from the grove to be used for combustion or animal feed, which minimizes nutrient recycling within the tree and in the tree-soil system. Moreover, to avoid any grazing damage to their trees, most olive growers do not allow sheep to graze weeds within their groves, which excludes any indirect manure input in those groves.

Our study revealed that variations in soil potassium and soil depth were the major factors affecting olive yield under our typical olive growing conditions. The importance of soil depth for olive production has already been shown by other studies in countries south of the Mediterranean (e.g., [46]), as deeper soils allow more water and nutrients to be stored and explored by tree roots. However, the effect of soil potassium is more controversial. The good correlations between fruit yield on the one hand and $\mathrm{K}_{\text {rootzone }} \mathrm{K}_{\text {topsoil }}$, and, to a lesser extent, leaf $\mathrm{K}$, on the other hand, provide evidence that the availability of this element can be critical for olive production. This finding enables us to confirm the observations of Hartmann et al. [47] in California, who compiled literature data showing a close relationship between productivity and leaf K. More recently, Jasrotia et al. [19] found a strong correlation between soil $\mathrm{K}$ and each of fruit set $\left(R^{2}=0.8\right)$ and olive yields $\left(R^{2}=0.81\right)$ in sub-Himalayan India. Jordão et al. [12] and Fernández-Escobar et al. [41] suggested that a large $\mathrm{K}$ demand by the reproductive structures of olive is responsible for a buildup of $\mathrm{K}$ in leaves during "off" years and a decline of that K during "on" years. Similarly, Kramer and Kozlowsky [48] indicated that fruits represent a strong sink for $\mathrm{K}$. Under variable Mediterranean conditions, foliar application of potassium significantly increased shoot growth [49] and olive yields [50]. This is probably because $\mathrm{K}$ increases plant 
resistance to drought and cold [51]. In addition, $\mathrm{K}$ deficiency makes olive leaves lose ability to regulate stomatal closure in irrigated conditions and even more under water-limited conditions [52], which makes plants more vulnerable to drought. It is also important to highlight that the authors who showed no effect of potassium addition attributed that either to the high level of potassium (inherent or due to previous fertilizations) in the soil $[15,38,53]$ or to the short duration of their studies [54].

The importance of soil $\mathrm{K}$ ahead of soil $\mathrm{N}$ is noteworthy. Soil $\mathrm{N}$ in our study ranked second in explaining the total variability observed and was even not significant when soil depth was included in the model. Although several papers emphasize the importance of $\mathrm{N}$ for olive production (e.g., $[38,55])$, some other authors (e.g., $[14,15]$ ) did not observe an effect of $\mathrm{N}$ fertilization on olive yields because leaf $\mathrm{N}$ was above sufficiency threshold.

The absence of correlations between yield on the one hand and leaves $\mathrm{N}$ and $\mathrm{P}$ on the other hand, contrarily to some literature reports, is probably due to mobilization of these minerals out of the leaves for active vegetative growth reproductive purposes. Loupassaki et al. [56] suggested the presence of sink competition between the fruits and the leaves for minerals and carbohydrates. The strongly negative correlations between yield and leaf nutrients $\mathrm{P}$ and $\mathrm{K}$ observed by Jasrotia et al. [16] provide further confirmation of this competition.

The low nutrient levels in the soil and leaves in our study stem from different factors. Erosion is a problem throughout Afrin area, and its negative effects on soil depth and fertility have been shown by other researchers (e.g., $[8,9])$. The lack of soil inputs to compensate for crop uptake and erosion losses is also contributing to this degradation problem.

Our results show that the model is substantially improved and the variability explained is increased up to $83 \%$ if leaf micronutrient concentrations are taken into consideration according to (4) above. The importance of including micronutrients in yield predicting models was also shown by Correia et al. [18] on carob tree (Ceratonia siliqua L.). However, it should be taken into account that leaf nutrient concentrations have seasonal variations and they change according to the bearing pattern (lower values in "on" years). Our model is therefore a good tool to estimate yield if leaf nutrient status is determined just before flowering. However, validation and calibration of this model under different conditions are needed.

Conducting this type of studies involves challenges related to the design and technical, statistical, and logistic levels. The statistical design and selection of trees that would represent a large area could be tricky tasks.

4.3. Strategies for Orchard and Nutrient Management. The results of this study show the importance of sound land management and soil conservation. Reducing up-down tillage and adopting minimum tillage options would decrease soil erosion rates. Our findings show the importance of replenishing the amounts of nutrients removed by the crop to improve olive productivity in this area. Alternative soil amendments (e.g., olive vegetation water) are being explored to improve soil fertility and olive yields in this low input system.

\section{Conclusion}

This field-scale study aimed to relate olive yields to soil and land parameters and tree nutritional status. Olive tree yield, soil fertility, and plant nutrition in our study area were lower than those in other Mediterranean areas of similar climatic conditions, mainly due to the prevailing low input olive production system and high erosion rates.

Our results showed that potassium is an element of prime importance for olive production, which helps explain the contradicting literature information with regard to the importance of this element for olive yields. Soil depth was another important factor and together with soil potassium explained $77 \%$ of the total variability. The variability explained by our model increased to $83 \%$ by incorporating leaf $\mathrm{B}$ and $\mathrm{Fe}$ concentrations. The information and regressions presented here contribute towards achieving a model that can predict and optimize olive production in areas of similar conditions. This model will need more data from other areas for calibration and validation, especially from areas of higher and lower rainfall as well as different soil types.

\section{Conflict of Interests}

The authors declare that there is no conflict of interests regarding the publication of this paper.

\section{Acknowledgments}

The guidance and contributions of late Mr. Malek Abdeen are gratefully acknowledged. Thanks are due to the farmers of Afrin area for their collaboration and help throughout this work. The authors would also like to acknowledge the excellent collaboration and facilitation provided by the Department of Agriculture and Agrarian Reform in Afrin and the Department of Olive Research in Idleb. Thanks are due to Piero Daltan for developing the GIS map of the area. They are thankful to George Estefan and his lab staff at ICARDA for the analyses of soil and plant material. They would also like to express their gratitude to the Soil Conservation and Land Management project at ICARDA for funding this work.

\section{References}

[1] J. De Graaff and L. A. A. J. Eppink, "Olive oil production and soil conservation in southern Spain, in relation to EU subsidy policies," Land Use Policy, vol. 16, no. 4, pp. 259-267, 1999.

[2] A. Loumou and C. Giourga, "Olive groves: the life and identity of the Mediterranean," Agriculture and Human Values, vol. 20, no. 1, pp. 87-95, 2003.

[3] F. Duarte, N. Jones, and L. Fleskens, "Traditional olive orchards on sloping land: sustainability or abandonment?" Journal of Environmental Management, vol. 89, no. 2, pp. 86-98, 2008.

[4] Consejería de Agricultura y Pesca-Junta de Andalucía, El Olivar Andaluz, Servicio de Publicaciones y Divulgacion, Sevilla, Spain, 2003. 
[5] A. Tubeileh, A. Bruggeman, and F. Turkelboom, Growing Olives And Other Tree Species In Marginal Dry Environments, ICARDA, Aleppo, Syria, 2004.

[6] C. Dingel, Market chain, livelihoods and land Management in mountainous olive production systems of north western Syria [M.S. thesis], Wageningen University, Wageningen, The Netherlands, 2006.

[7] R. J. Thomas, H. El-Dessougi, and A. Tubeileh, "Soil system management under arid and semi-arid conditions," in Biological Approaches to Sustainable Soil Systems, N. Uphoff, A. S. Ball, E. Fernandes et al., Eds., pp. 41-55, CRC Press, Boca Raton, Fla, USA, 2006

[8] A. Klewinghaus, F. Turkelboom, and A. Skowronek, "A GPS/GIS-integrated approach to the assessment of current soil erosion by water-experiences from Mediterranean NW-Syria," Annals of Geomorphology, vol. 142, pp. 281-305, 2006.

[9] S. Hoorelbeke, Impact of land use on land degradation in hilly olive orchards of NW-Syria [M.S. thesis], Catholieke Universiteit Leuven, Leuven, Belgium, 2005.

[10] R. J. Barneveld, A. Bruggeman, G. Sterk, and F. Turkelboom, "Comparison of two methods for quantification of tillage erosion rates in olive orchards of north-west Syria," Soil and Tillage Research, vol. 103, no. 1, pp. 105-112, 2009.

[11] L. Colen, F. Turkelboom, S. van Steenwinkel, K. Al Ahmed, J. Deckers, and J. Poesen, "How the soil moves upward in the olive orchards of nw syria: Sustainability analysis of a local innovation," Land Degradation and Development, 2013.

[12] P. V. Jordão, J. C. S. Dias, F. Calouro, and M. L. Duarte, “Effect of fertilization on the leaf macronutrient concentrations of olive tree," Acta Horticulturae, vol. 356, pp. 197-201, 1994.

[13] S. Perica, I. I. Androulakis, and M. Loupassaki, "Effect of summer application of nitrogen and potassium on the mineral composition of olive leaves," Acta Horticulturae, vol. 356, pp. 221-224, 1994.

[14] R. Fernández-Escobar and L. Marín, "Nitrogen fertilization in olive orchards," Acta Horticulturae, vol. 474, pp. 333-335, 1999.

[15] M. E. Marcelo and P. V. Jordão, "Effect of nitrogen and potassium on yield and some fruit quality parameters of olive tree," Acta Horticulturae, vol. 356, pp. 202-204, 1994.

[16] A. Jasrotia, R. P. Singh, V. P. Bhutani, and I. M. Singh, "Influence of tree characters and nutrient status of olive trees on their productivity," Acta Horticulturae, vol. 474, pp. 313-315, 1999.

[17] S. D. Sharma, R. P. Singh, and C. L. Sharma, "Periodical changes in foliar macronutrient status of olive," Acta Horticulturae, vol. 696, pp. 249-254, 2005.

[18] P. J. Correia, I. Anastácio, M. Da Fé Candeias, and M. A. Martins-Loução, "Nutritional diagnosis in carob-tree: relationships between yield and leaf mineral concentration," Crop Science, vol. 42, no. 5, pp. 1577-1583, 2002.

[19] Ministry of Agriculture and Agrarian Reform, The Annual Agricultural Statistical Abstract, Department of Planning and Statistics, Division of Agricultural Statistics, Damascus, Syria, 2007.

[20] M. Abdeen, A. Tubeileh, A. Al-Ibrahem, and F. Turkelboom, "Morphological characterization of nine Syrian olive (Olea europaea L.) cultivars," in Proceedings of the Conference on Promoting Community-Driven Conservation and Sustainable Use of Dryland Agrobiodiversity (ICARDA '05), Aleppo, Syria, April 2005.

[21] A. Tubeileh, F. Turkelboom, M. Abdeen, and A. Al-Ibrahem, "Fruit and oil characteristics of three main syrian olive cultivars grown under different climatic conditions," Acta Horticulturae, vol. 791, pp. 409-414, 2008.

[22] N. Cools, E. De Pauw, and J. Deckers, “Towards an integration of conventional land evaluation methods and farmers' soil suitability assessment: a case study in northwestern Syria," Agriculture, Ecosystems and Environment, vol. 95, no. 1, pp. 327-342, 2003.

[23] FAO, ISRIC, and ISSS, World Reference Base for Soil Resources, vol. 84 of World Soil Resources Reports, FAO, Rome, Italy, 1998.

[24] G. Blake, "Bulk density," in Methods of Soil Analysis, Part 1, C. A. Black, Ed., pp. 374-390, American Society of Agronomy, Madison, Wis, USA, 1965.

[25] A. Walkley and I. A. Black, "An examination of the Degtjareff method for determining soil organic matter, and a proposed modification of the chromic acid titration method," Soil Science, vol. 37, pp. 29-38, 1934.

[26] J. M. Bremner and C. S. Mulvaney, "Nitrogen-total," in Methods of Soil Analysis, A. L. Page, R. H. Miller, and D. R. Keeney, Eds., pp. 595-624, American Society of Agronomy, Madison, Wis, USA, 1982.

[27] S. R. Olsen and L. E. Sommers, "Phosphorus," in Methods of Soil Analysis, A. L. Page, R. H. Miller, and D. R. Keeney, Eds., pp. 403-427, American Society of Agronomy, Madison, Wis, USA, 1982.

[28] L. A. Richards, "Diagnosis and improvement of saline and alkaline soils," in Handbook 60, US Government Printing Office, Washington, D.C., USA, 1954.

[29] F. T. Bingham, "Boron," in Methods of Soil Analysis. Part 2, A. L. Page, R. H. Miller, and D. R. Keeney, Eds., pp. 431-448, American Society of Agronomy, Madison, Wis, USA, 2nd edition, 1982.

[30] W. L. Lindsay and W. A. Norvell, "Development of a DTPA soil test for zinc, iron, manganese, and copper," Soil Science Society of America Journal, vol. 42, pp. 421-428, 1978.

[31] A. Bouat, L'analyse foliaire et l'Olivier, Colloque Européen sur le Contrôle de la Nutrition Minérale et de la Fertilisation, Montpellier, France, 1964.

[32] A. Rashid, Mapping zinc fertility of soils using indicator plants and soils analysis [PhD dissertation], University of Hawaii, Honolulu, Hawaii, USA, 1986.

[33] M. H. Graham, "Confronting multicollinearity in ecological multiple regression,” Ecology, vol. 84, no. 11, pp. 2809-2815, 2003.

[34] SPSS, “SPSS release 14.0.1," SPSS Incorporation, 2005.

[35] M. Freeman, K. Uriu, and H. T. Hartmann, "Diagnosing and correcting nutrient problems," in Olive Production Manual, G. S. Sibbett, L. Ferguson, J. L. Coviello, and M. Lindstrand, Eds., pp. 83-100, University of California, Oakland, Calif, USA, 2nd edition, 2005.

[36] K. Gargouri and A. Mhiri, "Relationship between soil fertility and phosphorus and potassium olive plant nutrition," Options Méditerranéennes: Série A., vol. 50, pp. 199-204, 2002.

[37] H. Restrepo-Diaz, M. Benlloch, C. Navarro, and R. FernándezEscobar, "Potassium fertilization of rainfed olive orchards," Scientia Horticulturae, vol. 116, no. 4, pp. 399-403, 2008.

[38] J. Ferreira Llamas, "Tests and standardized trials used for olive tree fertilization," in International Course on the Fertilization and Intensive Cultivation of the Olive, pp. 30-52, UNDP/FAO/ Spanish National Institute for Agricultural Research, Cordoba, Spain, 1984. 
[39] A. Tubeileh, A. Bruggeman, and F. Turkelboom, "Effect of water harvesting on growth of young olive trees in degraded Syrian dryland," Environment, Development and Sustainability, vol. 11, no. 5, pp. 1073-1090, 2009.

[40] K. Dimassi, I. Therios, and A. Passalis, "Genotypic effect on leaf mineral levels of 17 olive cultivars grown in greece," Acta Horticulturae, vol. 474, pp. 345-348, 1999.

[41] R. Fernández-Escobar, R. Moreno, and M. García-Creus, "Seasonal changes of mineral nutrients in olive leaves during the alternate-bearing cycle," Scientia Horticulturae, vol. 82, no. 1-2, pp. 25-45, 1999.

[42] J. Ferreira Llamas, "Basis of fertilization in olive cultivation and the olive tree's vegetative cycle and nutritional needs," in International Course on the Fertilization and Intensive Cultivation of the Olive, pp. 1-25, UNDP/FAO/Spanish National Institute for Agricultural Research, Cordoba, Spain, 1984.

[43] R. Fernández-Escobar, T. García-Barragán, and M. Benlloch, "Estado nutritivo de las plantaciones de olivar en la provincia de Granada," Información Técnica Económica Agraria, vol. 1, pp. 39-49, 1994.

[44] I. I. Androulakis, M. H. Loupassaki, and W. W. Schwabe, "The content of mineral elements in the leaves of the olive cv. Koroneiki in relation to irrigation and the time of sampling," Acta Horticulturae, vol. 449, pp. 119-124, 1997.

[45] R. F. Korcak, "Iron deficiency chlorosis," Horticultural Reviews, vol. 9, pp. 133-186, 1987.

[46] B. Ben Rouina, A. Trigui, and M. Boukhris, "Effect of the climate and the soil conditions on crops performance of the "chemlali de sfax" olive trees," Acta Horticulturae, vol. 586, pp. 285-289, 2002.

[47] H. T. Hartmann, K. Uriu, and O. Lilleland, "Olive nutrition," in Fruit Nutrition, N. F. Childers, Ed., pp. 252-261, Horticultural Publications, Rutgers University, New Brunswick, NJ, USA, 1966.

[48] P. J. Kramer and T. T. Kozlowsky, Physiology of Woody Plants, Academic Press, New York, NY, USA, 1979.

[49] H. Restrepo-Díaz, M. Benlloch, and R. Fernández-Escobar, "Leaf potassium accumulation in olive plants related to nutritional $\mathrm{K}$ status, leaf age, and foliar application of potassium salts," Journal of Plant Nutrition, vol. 32, no. 7, pp. 1108-1121, 2009.

[50] A. H. A. Hussein, "Response of Manzanillo olive (Olea europaea, L.) cultivar to irrigation regime and potassium fertigation under tabouk conditions, Saudi Arabia," Journal of Agronomy, vol. 7, no. 4, pp. 285-296, 2008.

[51] P. Marschner, Marschner's Mineral Nutrition of Higher Plants, Academic Press, London, UK, 3rd edition, 2012.

[52] O. Arquero, D. Barranco, and M. Benlloch, "Potassium starvation increases stomatal conductance in olive trees," HortScience, vol. 41, no. 2, pp. 433-436, 2006.

[53] J. Ferreira, A. Garcia-Ortiz, L. Frias, and A. Fernández, "Los nutrientes N, P, K en la fertilización del olivar," Olea, vol. 17, pp. 141-152, 1986.

[54] M. Ben Mimoun, O. Loumi, M. Ghrab, K. Latiri, and R. Hellali, "Foliar potassium application on olive tree," in Proceedings of the IPI Regional Workshop on Potassium and Fertigation Development in West Asia and North Africa, Rabat, Morocco, September 2004.

[55] A. Jasrotia, R. P. Singh, J. M. Singh, and V. P. Bhutani, "Response of olive trees to varying levels of $\mathrm{N}$ and $\mathrm{K}$ fertilizers," Acta Horticulturae, vol. 474, pp. 337-340, 1999.
[56] M. H. Loupassaki, S. Perica, and I. I. Androulakis, "Seasonal changes in the olive fruit and the effects of summer-applied nitrogen and potassium," Advances in Horticultural Science, vol. 7, no. 2, pp. 65-68, 1993. 


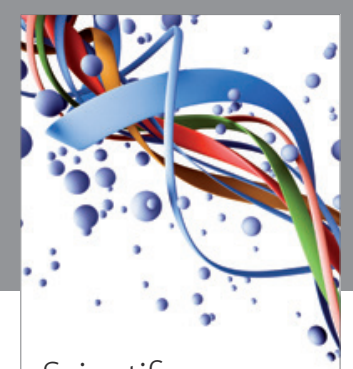

Scientifica
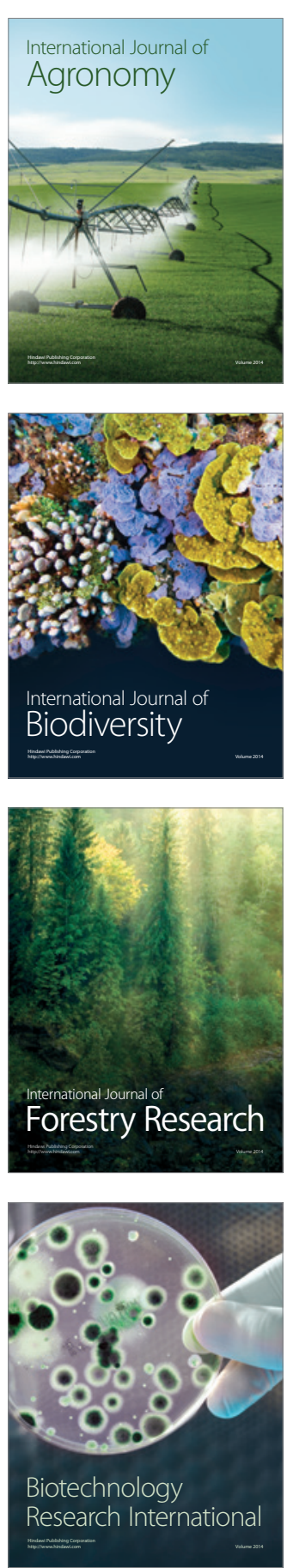
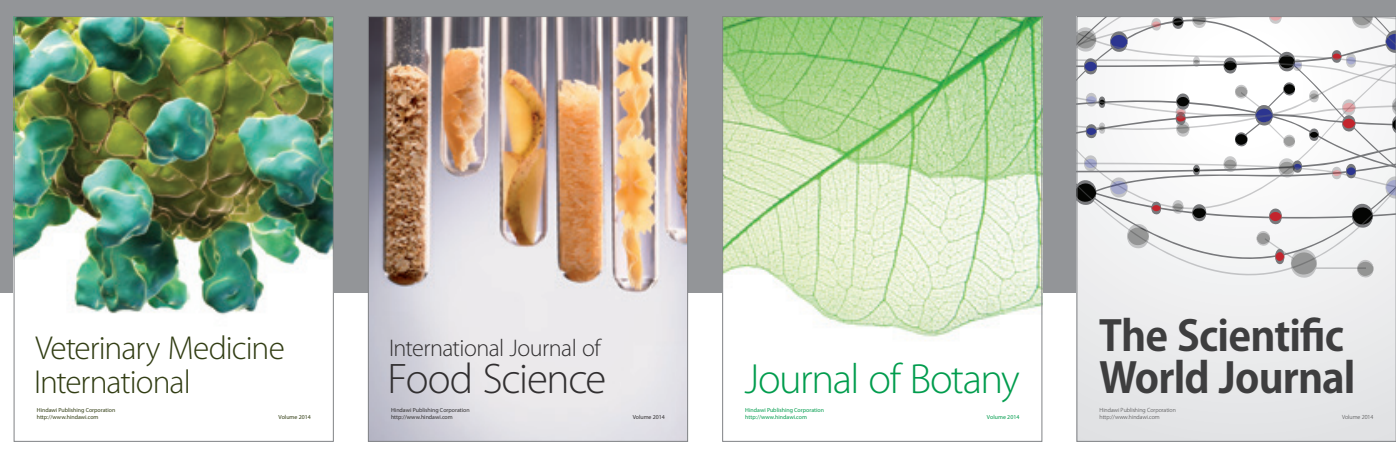

The Scientific World Journal
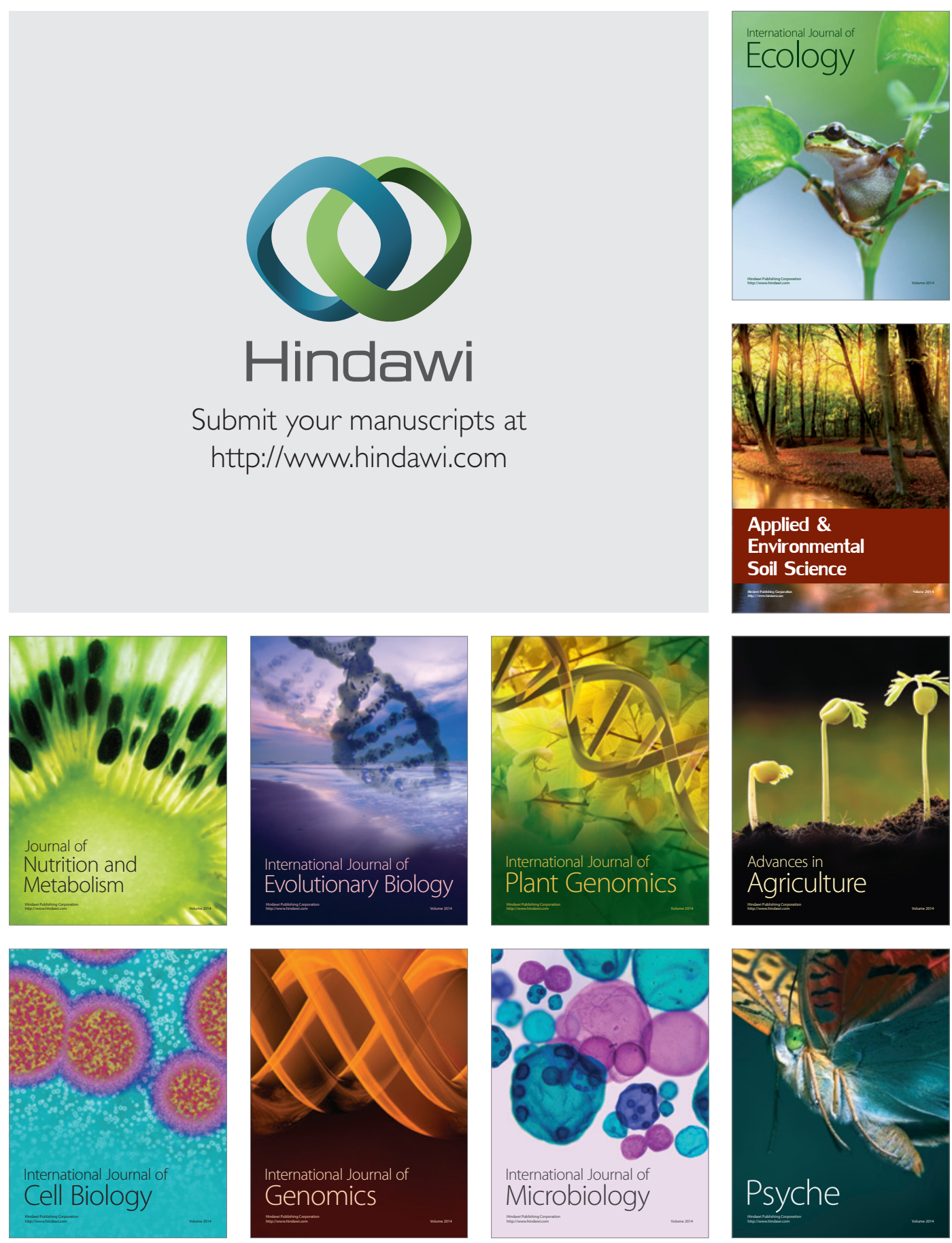